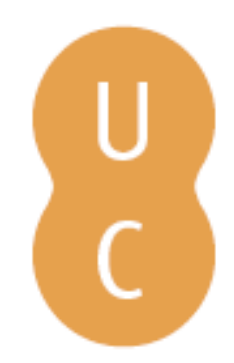

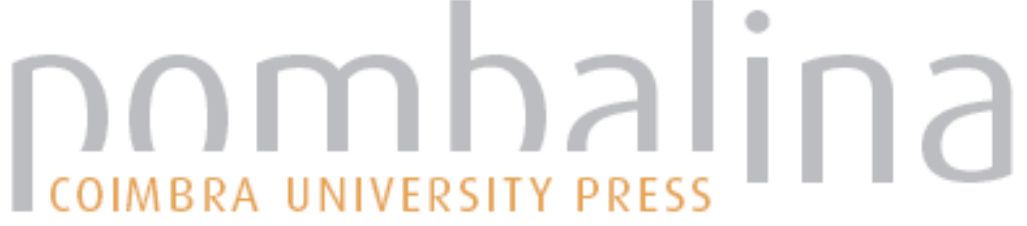

\section{Characterization of long term retardants}
Autor(es): $\quad$ Mans, Vicens; Espasa, Sheila
Publicado por: Imprensa da Universidade de Coimbra
URL persistente:
URI:http://hdl.handle.net/10316.2/44669
DOI:
DOI:https://doi.org/10.14195/978-989-26-16-506_152

Accessed : $\quad$ 26-Apr-2023 07:12:47

A navegação consulta e descarregamento dos títulos inseridos nas Bibliotecas Digitais UC Digitalis, UC Pombalina e UC Impactum, pressupõem a aceitação plena e sem reservas dos Termos e Condições de Uso destas Bibliotecas Digitais, disponíveis em https://digitalis.uc.pt/pt-pt/termos.

Conforme exposto nos referidos Termos e Condições de Uso, o descarregamento de títulos de acesso restrito requer uma licença válida de autorização devendo o utilizador aceder ao(s) documento(s) a partir de um endereço de IP da instituição detentora da supramencionada licença.

Ao utilizador é apenas permitido o descarregamento para uso pessoal, pelo que o emprego do(s) título(s) descarregado(s) para outro fim, designadamente comercial, carece de autorização do respetivo autor ou editor da obra.

Na medida em que todas as obras da UC Digitalis se encontram protegidas pelo Código do Direito de Autor e Direitos Conexos e demais legislação aplicável, toda a cópia, parcial ou total, deste documento, nos casos em que é legalmente admitida, deverá conter ou fazer-se acompanhar por este aviso.

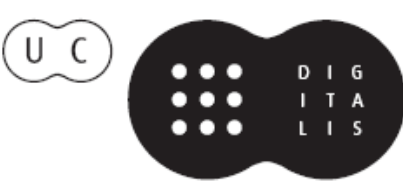




\section{ADVANCES IN}

\section{FOREST FIRE RESEARCH}

\section{8}

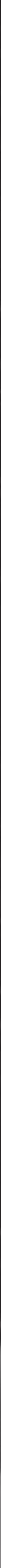


Short contribution - Fire Management

\title{
Characterization of long term retardants
}

\author{
Vicens Mans*; Sheila Espasa \\ "Budenheim Iberica, Extramuros s/n La Zaida, Zaragoza, Spain. \{vicente.mans@budenheim.com*, \\ sheila.espasa@budenheim.com\}
}

\begin{abstract}
Retardants are additives that once added to the water, the mix retards the fire spread by reducing the fuel flammability. There are two types of retardant, the so-called short term and long term. The difference among them is that short-term retardants are only effective when water is still there, while long-term retardants are effective even if water is evaporated.

The long-term retardants, retardants since now on and the base product for the presentation, modify the combustion process of the fuel, leading to a char formation instead of flammable gasses emission when it is submitted to pyrolysis. This particular aspect is well explained in the paper detailing the chemical reactions involved in the FR mechanism, such as here below case for the char formation mechanism to prevent flammable gases emission and avoid flame spread.
\end{abstract}

Keywords: retardants, forest fire fighting

\section{Characterization of long term retardants}

Besides the expected functionality of a retardant, the paper presents the regulatory aspects affecting the use of retardants, such as REACH compliance and Safety data Sheet required as per CE 1272/2008 for a safe use and application.

\section{Physical-chemicals parameters}

- Viscosity: The rheological properties of the retardants have a key influence in the air drops patterns ( $1 / \mathrm{m} 2$ left on the ground) and in the adhesion properties on the fuel (pine trees old forest needs higher viscosity than bushes). This parameter is measured for concentrated and mixed retardant (diluted with water at the end use condition) and are qualified as High (>1000 cp ), Medium ( 100$1000 \mathrm{cp})$ and Low viscosity (<100 cp)

- $\quad \mathrm{pH}$ : To determine acidity or alkalinity. Most of specs required a neutral $\mathrm{pH}$ ( 6-8 )

- Density: Retardants in form of a liquid concentrate use to have high densities $(1,4 \mathrm{Kg} / \mathrm{l})$. Mixed retardants density, typically $1,1 \mathrm{~kg} / \mathrm{l}$, is an important parameter since flying conditions are affected by the takeoff weight. Tested in both concentrate and mixed retardant.

- Freezing temperature. Temperature at which the liquid retardant concentrate turns into solid. This is an important parameter for winter storing of products. This effect is not important if the product can turn back into liquid after a temperature increase. Only tested in liquid concentrates.

- $\quad$ Active ingredient: The main component of the retardant is the responsible for the extinguishing capacity. The chemical reaction with the fuel to form char is based on an acidic dehydration of the cellulose. The acid is formed by ammonia release at $>250^{\circ} \mathrm{C}$ and the left acid is causing the dehydration. Two ammonium salts have been used for years: ammonium sulfate and ammonium phosphate/polyphosphate. Nowadays, ammonium sulfate is no longer used for two reasons: a) environmental reasons, b) Sulfates are not efficient for afterglow because SO3 is released and the catalytic effect is gone. Ammonium phosphates/polyphosphates remain because P2O5 is not volatile 
and remain on the fuel with a catalytic effect. Therefore, that characterization on the active ingredient is concentrated nowadays on the Phosphorous content, expressed as P2O5 as usual in fertilizer terminology. Tested in concentrates.

For solid FR concentrates, ammonium phosphates are used and for liquid FR concentrates, liquid ammonium polyphosphates are used.

\section{Performance characterization}

\subsection{Extinguishing efficiency.}

This is the most important parameter to qualify a retardant as such and be accepted in public tenders. Tests are run for mixed retardants according to the water dilution rate recommended by the manufacturer. There are three different tests and related assessments performed in three countries: a) Spain. A thermo-scale with a pine needles layer is $1 / 3$ treated with retardant, fire spread is measured, and ashes/residues weighted. With the test data, efficiency is rated from 0 to 4 . INIA is the responsible test institution. b) France: Two tests are performed: 1: Heat release determination. 2: Thermo-scale evaluating flame spread and weight loss. Fuel used are preconditioned wood chips. The Institution responsible for is CEREN. c) USA : For retardants that claim the $\mathrm{P} 2 \mathrm{O} 5$ concentration is above $8 \%$ in the mixed retardant, no test is required since experience proves that such concentration is enough to satisfy extinguishing properties. For concentrations below 8\%, mixed retardant are tested in a wind tunnel where pine needles on a long plate are ignited and flame spread and weigh loss is measured.

\subsection{Corrosion.}

This parameter is relevant regarding operations with retardant, mainly for aerial application. There is one common assessment method used by CEREN and USFS based on a 90 days weight loss of metal coupons immersed in the retardants. Alloys tested are: steel, copper brass, aluminum and magnesium (for helicopters with fix tank ). Testing conditions are total immersion, partial immersion, $20^{\circ} \mathrm{C}$ and $50^{\circ} \mathrm{C}$. There are some complementary methods, as inter-granular corrosion (USFS) or galvanic corrosion (CEREN). .

\subsection{Abrasion:}

Retardants contains solids in suspension, such as coloring agents, clay thickeners, that may cause abrasion problems in pumps, etc. tests method for such assessment are described in the presentation.

\subsection{Toxicity:}

The use of retardants shall not threat human health and environment. Testing and assessment described in OCDE and OPPTS ( EU and USA ) methodology.

\subsection{Impact on the flora.}

Retardants may cause seed germination problems due to the salinity concentration. The assessment method is based on the \% of germinated seeds compared with a blank sample. Typically, it is allowed a decrease of $50 \%$.

\subsection{Coloring.}

Retardants have to be identified from the air or ground in order to overlap air drops or ground applications.

Red color is the worldwide recognized color, which can be permanent (excluding rain washing) or fugitive (degraded by sun light). 
Assessment is made by visual methodologies, applied either on real vegetation or on laboratory application on white/black paper.

\subsection{Conclusions. Proposal for a EN standard for retardants assessment.}

Nowadays, technical requirements in public tenders in Spain are issued by each Autonomic Region. In France, Italy ... are issued by each of the Governments and it implies more than ten different specifications/requirements within EU. This lack of common assessments obviously imply difficulties for all stakeholders. The sector (Administrations, testing labs, suppliers,..) believe that a standardized assessment methodology would favor the competition, may avoid national trade barriers, and a common reference in the technical specification for retardants acquisition. For that purpose, the Spanish wildfire sector group in Tecnifuego, the fire safety association in Spain, that hosts the UNE/CTN23 Fire Safety technical Committee, has proposed to UNE the creation of a WG to develop such retardant assessment standard. This UNE standard will allow the different Spanish autonomies to specify according to this standard. Further, on, UNE can propose that standard as a draft to CEN to elaborate the EN standard. WG will be integrated by industry sector, institutions (INIA, UPC, UCO,..) and administrations ( Ministries,... ) 